\title{
From the Negotiating Arena to Conflict Management
}

\author{
David B. Lipsky \\ Ronald L. Seeber \\ Cornell University \\ Ariel C. Avgar \\ University of Illinois at Urbana-Champaign
}

\begin{abstract}
Richard Walton and Robert McKersie's A Behavioral Theory of Labor Negotiations has influenced generations of scholars who have studied conflict resolution and negotiations, as well as countless negotiation practitioners (Walton and McKersie 1991; for an assessment of Walton and McKersie's influence on research and practice, see Kochan and Lipsky 2003). In this article, we extend Walton and McKersie's theory, which focused on the negotiations between unions and employers, to consider its implications for the strategic choices made by organizations as they develop conflict management policies. We begin by discussing Walton and McKersie's influence on the language that both scholars and practitioners use to describe not only negotiating behavior but also the strategies organizations pursue to manage workplace conflict.
\end{abstract}




\section{The Rhetoric of Negotiations}

Kleenex, originally a specific product name, ultimately became a term commonly used by the public and marketers to refer to all versions of tissue most people use. Likewise, the original works on game theory contributed terminology that people now use widely without understanding its origin. Nearly everyone uses the terms "zero-sum" and "non-zero-sum" without attribution to those who originally coined those terms (Von Neumann and Morgenstern 1944; Nash 1950) or an understanding of their theoretical meaning. Similarly, the four sub-processes of labor negotiations - distributive bargaining, integrative bargaining, intraorganizational bargaining, and attitudinal structuring identified by Walton and McKersie have been widely adopted by practitioners and students.

A cursory search of academic and applied work reveals the near universality of the terms distributive and integrative bargaining in particular. The sophistication of the behavioral theory is lost on too many authors, who typically view distributive and integrative bargaining as a binary choice rather than a continuum. Walton and McKersie always stressed that negotiation was an exercise in mixedmotive decision making, presenting negotiators with an ongoing dilemma of whether to lean primarily in a distributive or integrative direction. Through generations of research and practice, however, these terms have entered the popular lexicon to signify a choice negotiators must make between competing with the other party (i.e., using distributive bargaining) and cooperating (i.e., using integrative bargaining).

Moreover, the terms distributive and integrative bargaining have come to have a set of meanings and values that extend beyond their core meaning as defined by Walton and McKersie. For example, many individuals who lack experience or sophistication view integrative bargaining as "good" and distributive bargaining as "bad." They consider integrative bargaining as a means to expand the proverbial "pie" and distributive bargaining as a means to divide the pie. They believe integrative bargaining serves a higher calling, while distributive bargaining is coarse and crude, both tactically and strategically.

Experienced negotiators, however, are well aware of the inadequacy of that simple dichotomy. It is truly difficult to characterize virtually any negotiation as either entirely integrative or entirely distributive in nature. More importantly, Walton and McKersie made no such judgment, viewing distributive and integrative bargaining in terms of a spectrum rather than a dichotomous choice. Each end of the spectrum has a distinct subset of negotiation strategies and tactics, and employing one subset may be perfectly appropriate under some circumstances but not in others. But in the classroom we convey the distinction as a clear-cut choice, and rarely do we make reference to the richness of the examples that Walton and McKersie provided in their original work. Nonetheless, as oversimplified as these ideas may have become in popular use, their inclusion in the popular lexicon suggests the enduring influence of the behavioral theory.

The other two critical elements of the behavioral theory, namely attitudinal structuring and intraorganizational bargaining, have been less widely adopted in the popular language but have been enormously influential among scholars and practitioners. Not only did Walton and McKersie point out the importance of these processes, but the terms they used to define the processes have become part of the standard teaching and research on collective bargaining. Nearly every course on collective bargaining devotes considerable time to understanding the divergence between the interests of union 
leaders and union members and the tactical and strategic choices each side makes to influence the other.

The behavioral theory's original purpose in delving into intraorganizational bargaining was to help us understand collective bargaining, but Walton and McKersie could not have foreseen the influence the idea of intraorganizational bargaining (or "internal negotiation") would have on the language of organizational behavior. Although students of business organizations have long understood the importance of the dynamics within a board of directors, the link between the internal interests of both unions and business organizations was not widely understood prior to Walton and McKersie's work. Notwithstanding the awkwardness of the term intraorganizational bargaining, it has worked its way into the standard language of organizational behavior, institutional economics, and even political science.

Attitudinal structuring, on the other hand, is not as widely used a term, but scholars recognize that negotiators universally apply this process in practice. Attitudinal structuring includes all attempts by negotiators to manage their relationship, as well as the values that the negotiators and other stakeholders assign to the specific issues in conflict. Walton and McKersie were the first scholars to recognize that the attitudes and behaviors that arise from a negotiation are sometimes as important as the substantive issues. Although defining this concept did not influence the rhetoric of negotiations, it has surely driven the behavior of negotiators.

\section{Strategic Choice in Industrial Relations and Conflict Management}

In addition to its tremendous influence on negotiation rhetoric, Walton and McKersie's seminal work built the foundation for a strategic theory of industrial relations that took hold almost two decades after the publication of $A$ Behavioral Theory of Labor Negotiations and transformed the study of labor and employment relations. Walton and McKersie's emphasis on actors' strategies and tactics across the four negotiations sub-processes laid the groundwork for what is now referred to as the strategic choice framework. As such, alongside its lasting contribution to a more complex understanding of negotiation processes and outcomes, the behavioral theory has also contributed greatly to a more nuanced understanding of the actor-driven dynamics that influence interactions between and within labor and management.

Interestingly, conflict management researchers have recently begun to apply a strategic choice framework to the study of how organizations adopt dispute resolution practices. Thus, fifty years after its publication, Walton and McKersie's behavioral theory is now shaping the study of conflict management (see, e.g., Lipsky and Avgar 2008; Lipsky, Avgar, and Lamare 2014). Even more fascinating is the fact that this latest stream of research focuses on a different level of analysis-the organization as opposed to the negotiating parties - and is primarily concerned with the management of conflict in nonunion settings. This further exemplifies the behavioral theory's "staying power," as well as its modern-day relevance for workplace phenomena that extend well beyond traditional labormanagement negotiations.

The concept of strategic choice, which received extensive attention in another book coauthored by McKersie in 1986 (see Kochan, Katz, and McKersie 1986; see also Kochan, McKersie, and 
Cappelli 1984), is built on the notion that industrial relations actors (employers and unions) make a series of choices or decisions about how to engage with their counterparts. The roots of this concept extend back to the behavioral theory, which suggests that negotiations outcomes are products of choices with respect to the four sub-processes (integrative and distributive bargaining, attitudinal structuring, and intraorganizational negotiating). Labor and employment relations outcomes, according to this approach, are not merely the product of environmental, economic, or institutional pressures, but also vary as a function of managers' and union leaders' conscious strategic choices. In other words, industrial relations dynamics and outcomes are neither predetermined nor institutionally constrained, nor are they tightly governed by the "web of rules" that John Dunlop viewed as essential to the functioning of an industrial relations system (Dunlop 1958). Rather, industrial relations actors have a substantial degree of control over employer and employee outcomes, which are shaped by the deliberate strategies they employ, the choices they make, and the associated actions they take. It is this strategic dimension that helped Thomas Kochan, Harry Katz, and Robert McKersie (1986) explain the large amount of variation they observed in industrial relations activity across different organizations and settings.

The concept of strategic choice has, in some ways, come full circle and has recently been applied to the study of organizational conflict management. In our own work, we have examined the relationship between firms' strategic orientations and the conflict management practices they adopt and use (see Avgar et al. 2013; Lipsky, Avgar, and Lamare 2014). We find that the strategic orientations that guide and influence the adoption of conflict management practices vary across firms. Some firms, for example, adopt such practices primarily to avoid litigation, some do so as a way to enhance managerial and problem-solving competencies, and still others view conflict management practices as an effective means of increasing organizational efficiencies and reducing costs. Our empirical research also finds that variation in strategic orientation is associated with the adoption of different types of conflict management practices. In other words, organizational actors shape the way in which conflict is managed inside the firm as a function of, among other things, their strategic expectations and choices.

Just as Walton and McKersie argued that negotiators can use different behaviors and tactics to advance beneficial outcomes, we maintain that firms that seek to advance preferred conflict management outcomes should deliberately align their practices with the benefits they seek to attain. Organizations, like negotiating parties, have substantial agency in how they structure and manage a central and prevalent employment relations activity - the resolution of workplace conflict. This insight, like so many others in our field, is rooted in the paradigmatic shift that Walton and McKersie brought about in 1965.

\section{Internal Dynamics: The Organization and Institutionalization of Conflict Management Policies}

Intraorganizational bargaining is an activity that responds to conflict within an organization. Organizations, Walton and McKersie point out, "usually lack internal consensus about the objectives they will attempt to obtain. ... Different elements of the organization may have different ideas about the priorities assigned to various objectives being pursued, or they may disagree on what should be minimally acceptable. ... Similarly, there may be a lack of consensus about what type of relationship should be developed with [other parties]" (Walton and McKersie 1991: 281). Clearly, intraorganizational bargaining, or internal negotiation, is not confined to conventional negotiation or even conflict 
management, but is a more encompassing phenomenon essential for understanding the development of most of the strategies, policies, and practices of organizations.

Our research over the last twenty years has revealed that intraorganizational, or internal, conflict has often been a major problem in instituting conflict management policies. In some organizations, it has even led to their abandonment. A common manifestation of internal conflicts are so-called "turf wars," between one function or department and another (e.g., human resources and the legal department), or one stakeholder and another, and those internal conflicts can sometimes cause high-level managers to leave the organization.

Space constraints limit our discussion to two internal challenges: (1) Which function in the organization should be responsible for managing its conflict management policies? (2) How can the organization achieve stability and permanence in its conflict management policies? Elsewhere we have discussed how conflict management policies "become a more or less permanent part of the fabric of the organization" and called that process "institutionalization" (Lipsky, Seeber, and Fincher 2003: 309).

\section{The Responsibility for Managing Conflict Management Policies}

Practitioners and scholars have debated what are the "best practices" for managing an organization's alternative dispute resolution (ADR) practices and conflict management policies. The responsibility may be given to the human resources function or the legal affairs department, or the organization may create an autonomous or semi-autonomous office to manage these policies. (We have also discovered hybrid versions of these organizational arrangements.)

The choice an organization makes depends in part on its conception of the nature of conflict resolution. Organizations that believe that the resolution of workplace conflict is principally a management function and managing workplace conflict needs to be aligned with the organization's other employment relations policies will assign the responsibility to the human resources function. Organizations that view the resolution of workplace conflict as essentially litigation management will give the responsibility to their legal department.

Many knowledgeable experts have argued, however, that the preferred approach, especially if the organization has a conflict management system, is to establish an autonomous office. For example, more than a decade ago, a task force established by what was then called the Society of Professionals in Dispute Resolution (SPIDR) (now the Association for Conflict Resolution) to examine best practices in conflict management strongly recommended the use of an autonomous office. The task force stated that the challenge of a conflict management system is "managing turf battles between departments over ownership of a particular dispute resolution process.... [M]any different departments and stakeholders must work collaboratively and deliver the same message" in support of the system. The experts on the SPIDR task force thought that an autonomous office would be in the best position to avoid turf battles and foster collaboration across departments and stakeholders (Gosline et al. 2001: 1415).

In 2013, Cornell University co-sponsored a survey with the International Institute of Conflict Prevention and Resolution (CPR) of so-called "cutting edge" ADR companies that focused specifically on how these organizations managed their conflict resolution policies. The survey targeted about one 
hundred corporations that were known to have innovative policies (a substantial proportion had implemented a conflict management system). Of the fifty-one corporations that responded to the survey, twenty-six assigned the responsibility for managing their conflict resolution policies to the corporate legal department, thirteen gave the responsibility to their human resource function, and twelve used an autonomous office or an ombudsman (Lipsky 2014: 7-8). We note that the standards of practice issued by the International Ombudsman's Association seriously limit, and in fact proscribe, an ombudsman's role in "managing" any line or staff function in the organization; however, an ombudsman may have an important (albeit informal and often invisible) role in coordinating a conflict management system, and a growing number do so (Howard 2010; Rowe and Williams 2014).

The most fully developed version of a conflict management system is a so-called "integrated conflict management system" or ICMS (Gosline et al. 2001; Lipsky, Seeber, and Fincher 2003). Although the use of a conflict management system is growing in both private and public sector organizations, the use of a genuine ICMS is still limited (see, e.g., Avgar et al. 2013). A key element of an ICMS is that virtually everyone in an organization shares responsibility for managing it, including line and middle managers, as well as rank-and-file employees. But this is obviously a difficult system to implement, and as Mary Rowe (2015) has noted (in correspondence with the authors), "[t]his is one of the reasons that real (not paper) management of an ICMS is such a complex subject."

Surprisingly, we have little data-based empirical evidence on the relationship between how an organization manages its conflict resolution policies and the effectiveness of those policies. What we currently know is based almost entirely on case studies and anecdotal evidence, as well as the experience of practitioners who have been "in the trenches."

\section{The Institutionalization of Conflict Management Policies}

Collaboration across departments and stakeholders in an organization is usually essential if the organization expects to institutionalize its conflict management policies. But conflict between and among stakeholders and departments almost always limits collaboration. Even if an autonomous office manages conflict resolution policies, we have discovered that internal conflict is difficult to avoid. For example, in a federal agency we have studied, the deputy counsel in the agency's legal department became an ardent champion of ADR, and largely because of her leadership, the agency instituted a set of progressive ADR policies. Some of the line managers in the agency, however, viewed ADR principally as a means of second-guessing their decisions. The turf battle that erupted between the deputy counsel and the line managers caused the deputy counsel to leave the agency, and her departure undermined the agency's commitment to ADR and limited the institutionalization of its ADR policies.

In some cases, we have discovered, the departure of the ADR champion can lead to the demise of the organization's ADR policies. For example, we have studied the Prudential Corporation for nearly twenty years. In our 2003 book, we wrote, "Prudential was ... the object of a series of embarrassing lawsuits and SEC [Securities and Exchange Commission] investigations in the 1990s. One lawsuit resulted in Prudential's agreeing to pay $\$ 2$ billion to over 1 million policyholders who sought restitution for abuses in the company's life insurance sales practices" (Lipsky, Seeber, and Fincher 2003: 149). As a consequence of the corporation's legal troubles, it established a sophisticated conflict management system in 1999. It used an autonomous office to run the system, and hired a first-rate attorney to be 
head of that office (Lipsky, Seeber, and Fincher 2003). For the next ten years, the office operated effectively and the corporation avoided major lawsuits. But the head of the office then retired, and his second-in command, whom he had groomed to be his replacement, also left the organization. The corporation had no apparent replacement to head its conflict management function. More importantly, the organization apparently "forgot" why it had established a conflict management system in the first place. Consequently the system deteriorated.

Our research suggests that a lack of an institutional memory can hamper the institutionalization of conflict management policies. The turnover of managers, including those who lead the ADR function, can cause the organization to lose sight of what its original motives were for adopting ADR and conflict management policies. In the competition for an organization's scarce resources, ADR champions sometimes discover that their priorities and interests are subordinated to those of other departments and stakeholders in the organization.

\section{Conclusion}

In an earlier assessment of the influence of Walton and McKersie's seminal book, Kochan and Lipsky wrote, "Nowhere has the theory and practice of negotiations had as big an effect as on the use of alternative dispute resolution in organizations"(Kochan and Lipsky 2003: 4). At that time, more than a decade ago, it was already apparent that the behavioral theory was useful in understanding the rise of ADR policies and practices. Since then, we submit, using both the rhetoric and the substance of the behavioral theory casts considerable light on the strategic choices organizations have made in managing workplace conflict.

Extending from the practice of negotiation to the strategies of conflict management, Walton and McKersie have been the great teachers of an ever-growing number of conflict resolution scholars and practitioners. As Henry Adams famously wrote, "A teacher affects eternity: he can never tell where his influence stops."

\section{NOTE}

The authors would like to thank Mary Rowe for her helpful comments on an earlier version of this article. We would also like to thank Missy Harrington for her very able assistance. 


\section{REFERENCES}

Avgar, A. C., J. R. Lamare, D. B. Lipsky, and A. Gupta. 2013. Unions and ADR: The relationship between labor unions and workplace dispute resolution in U.S. corporations. Ohio State Journal on Dispute Resolution 28(1): 63-106.

Dunlop, J. T. 1958. Industrial relations systems. New York: Henry Holt and Company. 412 Lipsky, Seeber, and Avgar From the Negotiating Arena to Conflict Management

Gosline, A., L. Stallworth, M. C. Adams, N. Brand, C. J. Hallberlin, C. S. Houk, D. B. Lipsky, J. Lynch, N. E. Peace, M. Rowe, and A. Thomas. 2001. Designing integrated conflict management systems: Guidelines for practitioners and decision makers in organizations. Ithaca, NY: Institute on Conflict Resolution, Cornell University.

Howard, C. L. 2010. The organizational ombudsman: Origins, roles, and operations - A legal guide. Chicago: ABA Publishing.

Kochan, T. A., H. C. Katz, and R. B. McKersie. 1986. The transformation of American industrial relations. Ithaca, NY: Cornell University Press.

Kochan, T. A., and D. B. Lipsky (eds). 2003. Negotiations and change: From the workplace to society. Ithaca, NY: Cornell University Press.

Kochan, T. A., R. B. McKersie, and P. Cappelli. 1984. Strategic choice and industrial relations theory. Industrial Relations 23(1): 16-39.

Lipsky, D. B. 2014. How leading corporations use ADR to handle employment complaints. In Cuttingedge advances in resolving workplace disputes, edited by J.W. Waks, N. L. Vanderlip, and D. B. Lipsky. New York: The International Institute for Conflict Prevention and Resolution.

Lipsky, D. B., and A. C. Avgar. 2008. Toward a strategic theory of workplace conflict management. Ohio State Journal on Dispute Resolution 24(1): 143-190.

Lipsky, D. B., A. C. Avgar, and J. R. Lamare. 2014. Conflict resolution in the United States. In The Oxford handbook of conflict management in organizations, edited by W. K. Roche, P. Teague, and A. J. S. Colvin. Oxford: Oxford University Press.

Lipsky, D. B., R. L. Seeber, and R. D. Fincher. 2003. Emerging systems for managing workplace conflict: Lessons from American corporations for managers and dispute resolution professionals. San Francisco: Jossey-Bass.

Nash, J. F. 1950. The bargaining problem. Econometrica 18(2): 155-162.

Rowe, M. 2015. Personal e-mail message to D. Lipsky, May 25.

Rowe, M., and R. Williams. 2014. Organizational ombudsman. In Cutting edge advances in resolving workplace disputes, edited by J. W. Waks, N. L. Vanderlip, and D. B. Lipsky. New York: International Institute for Conflict Prevention and Resolution.

Von Neumann, J., and O. Morgenstern. 1944. Theory of games and economic behavior. Princeton, NJ: Princeton University Press. 
Walton, R. E., and R. B. McKersie. 1991. A behavioral theory of labor negotiations: An analysis of a social interaction system, 2nd edn. Ithaca, NY: ILR Press. 